\title{
Is the Precariat a Class? ${ }^{1}$
}

\section{Erik Olin Wright, University of Wisconsin, United States of America}

\begin{abstract}
Precariousness is a pervasive and increasing condition of life in both the developed and less developed regions of the world. Guy Standing has proposed a reconceptualisation of these trends from precarity as a condition to the precariat as a class distinct from the working class. This article presents a Marxist critique of this reconceptualisation on two principle grounds: first, that the material interests of people in the precariat and in the working class are not sufficiently opposed to each other for these to constitute two distinct classes; and second, that across the various segments of the precariat the optimal strategies for securing a livelihood are not sufficiently unified for the precariat as a whole to constitute a class.
\end{abstract}

\section{KEY WORDS}

precariat; class analysis; Marxism

The importance of the increase in economic insecurity and precariousness of employment which began in the 1980s and has accelerated since then has been broadly recognised by analysts of contemporary capitalism. The reconceptualisation of these trends from precarity as a condition to the precariat as a class is much more controversial. In what follows I will develop a Marxist critique of the arguments for this view by its most influential advocate, Guy Standing, in his two books, The Precariat and The Precariat Charter (Standing, 2011, 2014). I will emphasise two principle points: First, to be constituted as a class distinct from the working class, the precariat must have material interests that are clearly differentiated from those of the working class. I will argue that this is not in general the case, whether we define material interests in terms of the opposition of capitalism versus socialism or in terms of alternative rules of the game of capitalism. Second, if we look more narrowly at material interests in terms of concrete strategies for securing a livelihood within the existing rules of the game, then people within a given class should share broadly similar optimal strategies. In the case of the precariat, the different segments identified by Standing have sharply different strategies of survival and advancement. The precariat is thus neither a class in terms of the differentiation of class interests from workers, or in terms of the unity of interests across its segments.

I begin by outlining Standing's basic analysis of the precariat and his arguments for why it should be considered a class. I then examine the place of the precariat within a broad understanding of class analysis. I argue that while the precariat can be situated within class analysis it is not useful to treat it as a distinct class in its own right.

\footnotetext{
${ }^{1}$ Much of this paper comes from Chapters 6 and 9 of Understanding Class (Verso, 2015) by Erik Olin Wright.
} 


\section{Guy Standing's Arguments for Why the Precariat is a Class}

Standing grounds his arguments that the precariat is a class in a quite complex three-dimensional definition of class:

Class can be defined as being determined primarily by specific 'relations of production', specific 'relations of distribution' (sources of income), and specific relations to the state. From these arises a distinctive 'consciousness' of desirable reforms and social policies (Standing, 2014: 13).

The explicit inclusion of relations to the state is quite distinctive here. While many class analysts see the relationship of classes to the state as an important issue, few build this into the very definition of class structures. Standing does so because he believes that one of the pivotal aspects of the lived reality of the position of the precariat in contemporary capitalism centres on the increasing marginalisation of many people from the rights normally associated with citizenship. It is really the intersection of economic precarity with political marginality that most sharply creates a boundary dividing the precariat from the working class.

On the basis of the three dimensions of relations - relations of production, relations of distribution and relations to the state - Standing identifies seven classes that comprise the class structure of contemporary capitalist societies:

1. The elite or plutocracy, a true ruling class in the classical Marxist sense. In Standing's words: “They are not the 1 per cent depicted by the Occupy movement. They are far fewer than that, and exercise more power than most people appreciate. Their financial strength shapes political discourse, economic policies and social policy" (Standing, 2014: 13).

2. The salariat, defined as people in "stable full-time employment, some hoping to move into the elite, the majority just enjoying the trappings of their kind, with their pensions, paid holidays and enterprise benefits, often subsidized by the state. The salariat is concentrated in large corporations, government agencies and public administration, including the civil service" (Standing, 2014: 12).

3. Proficians, a term that "combines the traditional ideas of 'professional' and 'technician' but covers those with bundles of skills that they can market, earning high incomes on contract, as consultants or independent own-account workers" (Standing, 2011: 12-13).

4. The old "core" working class (proletariat), "defined by its reliance on mass labour, reliance on wage income, absence of control or ownership of the means of production, and habituation to stable labour that corresponded to its skills" (Standing, 2014: 15).

5. The precariat.

6. The unemployed.

7. The lumpen-precariat (or "underclass"), identified by Standing as "a detached group of socially ill misfits living off the dregs of society" (Standing, 2011: 13).

Standing's objective is not to provide careful, analytically rigorous definitions of each of these; he is really only concerned with differentiating the precariat from the rest of the class structure, especially from the working class. The result is that he provides only a vague set of demarcations and rationales for some of these categories. For example, it is not at all clear from his analysis how non-managerial white-collar and credentialed employees in stable jobs in the state and private sectors should be treated. 
They do not seem part of the core working class, which Standing identifies with manual labour, but they also do not fit comfortably into his definition of the salariat since that category also includes top corporate executives "hoping to move into the elite", nor do they fit into his category of proficians who are highly mobile, educated, own-account workers. This lack of precision in specifying the criteria for the class location of white-collar workers would be a more serious problem if Standing were attempting to generate a rigorous general class map of contemporary capitalism, but he is not. His goal is to defend the concept of the precariat and provide a fine-grained account of the characteristics which distinguish it from the working class. The question, then, is whether he provides a compelling argument that this particular line of demarcation - between the working class and the precariat constitutes a class division.

Standing approaches this problem by contrasting workers and the precariat in terms of the three dimensions of class relations.

\section{Distinctive relations of production}

In identifying the criteria which differentiate the precariat from the proletariat, Standing does not explicitly give any one of the three dimensions of class relations more weight than others. Still, the first of these - the relations of production - seems to be the most fundamental in anchoring the concept and giving the concept its name. In terms of the relations of production, he writes, "The precariat consists of people living through insecure jobs interspersed with periods of unemployment or labour-force withdrawal (misnamed as 'economic inactivity') and living insecurely, with uncertain access to housing and public resources." Standing sees these relations of production as sharply differentiating the precariat from the proletariat:

The precariat was no part of the 'working class' or the 'proletariat'. The latter terms suggest a society consisting mostly of workers in long-term, stable, fixed-hour jobs with established routes of advancement, subject to unionization and collective agreements, with job titles their fathers and mothers would have understood, facing local employers whose names and features they were familiar with (Standing, 2011: 10).

The working class was expected to supply stable labour, even if its members were subject to unemployment. The term that characterized their working lives was proletarianization, habituation to stable full-time labour..... Whereas the proletarian norm was habituation to stable labour, the precariat is being habituated to unstable labour (Standing, 2014: 15, 17).

Standing elaborates this core idea of insecurity by arguing that the precariat lacks "the seven forms of labour-related security" that characterised the working class following the Second World War: labour market security (adequate income-earning opportunities); employment security (protection against arbitrary dismissal, regulations on hiring and firing, etc.); job security (ability and opportunity to retain a niche in employment); work security (protections against accidents and illness at work); skill reproduction security (opportunity to gain skills through apprenticeships); income security (assurance of adequate stable income); representation security (possession of a collective voice in the labour market through independent trade unions with a right to strike) (Standing, 2011: 17). The absence of the first five of

these forms of security are aspects of the distinctive form of relations of production of the precariat.

Global Labour Journal, 2016, 7(2), Page 125 


\section{Distinctive relations of distribution}

Income, Standing notes, comes in a wide variety of forms: "own-account production, income from producing or selling to a market, money wages, enterprise non-wage benefits, community and solidarity benefits, state benefits, and income from financial and other assets" (Standing, 2014: 18). The distinctive characteristic of the precariat is that it lacks access to all of the non-wage sources of income:

...during the twentieth century, the trend was away from money wages, with a rising share of social income coming from enterprise and state benefits. What distinguishes the precariat is the opposite trend, with sources of income other than wages virtually disappearing... The precariat lacks access to non-wage perks, such as paid vacations, medical leave, company pensions and so on. It also lacks rights-based state benefits, linked to legal entitlements, leaving it dependent on discretionary, insecure benefits, if any. And it lacks access to community benefits, in the form of a strong commons (public services and amenities) and strong family and local support networks (Standing, 2014: 18-19).

The critical issue here, I think, is the increased vulnerability people face when their material standard of living comes entirely from money wages, with no social safety net, community back-up or other sources of benefit. The standard of living of the working class, in this account, remains underwritten by forms of income other than money wages, even though these may be declining in the era of austerity. For the precariat, those benefits have largely disappeared. The combination of employment instability and income vulnerability defines the economic precarity of the precariat.

\section{Distinctive relations to the state}

While the various aspects of economic precarity may be the most obvious factors that contribute to the precariat being constituted as a class, Standing also feels that its distinctive relations to the state are critical in creating a real boundary between it and the working class. He builds his analysis around the contrast between "citizens" and "denizens": Citizens are people with full rights granted by the state; "denizens" are mere residents who live under the jurisdiction of the state, but with much more limited rights. "The precariat", Standing writes, "lacks many of the rights provided to citizens in the core working class and salariat. Members of the precariat are denizens" (Standing, 2014: 20). Traditionally non-citizen migrants were denizens in this sense: they had permission to live somewhere, but with a much more limited set of politically-guaranteed rights. This condition, Standing argues, has now been extended to a significant number of people who remain formally citizens. In contrast, for the working class these rights remain largely intact.

The precariat is thus defined by three overarching criteria: precariousness within the relations of production, vulnerability within the relations of distribution, and marginality within the relations to the state. While some segments of the working class may share some of these characteristics, taken

\footnotetext{
2 Included in this discussion of rights are political rights ("the precariat is relatively disenfranchised"), civil rights ("the precariat is losing rights to due process"), cultural rights ("Governments are demanding more conformity to societal norms and majoritarian institutions, intensifying cultural marginalization of minorities") and economic and social rights ("the precariat is losing social and economic rights, notably in the sphere of state benefits and the right to practice an occupation") (Standing, 2014: 20-21).
}

Global Labour Journal, 2016, 7(2), Page 126 
together they constitute the precariat as a distinct class. ${ }^{3}$

This does not mean that there are no divisions within the precariat. In the second decade of the twenty-first century, Standing argues, the precariat in the developed capitalist world is internally divided into three main sub-categories. The first comprises people who were previously firmly within the working class but who have been marginalised by the trajectory of capitalist development. They are "people bumped out of working-class communities and families. They experience a sense of relative deprivation. They, their parents or grandparents belonged to working-class occupations, with status, skill and respect" (Standing, 2014: 29). The second variety "consists of traditional denizens migrants, Roma, ethnic minorities, asylum seekers in limbo, all those with the least secure rights anywhere. It also includes some of the disabled and a growing number of ex-convicts" (Standing, 2014: 29). And the third variety, which Standing feels is the dynamic core of the precariat, "consists of the educated, plunged into a precariat existence after being promised the opposite, a bright career of personal development and satisfaction. Most are in their twenties and thirties. But they are not alone. Many drifting out of a salariat existence are joining them. ... They are not doing what they set out to do, and there is little prospect of doing so" (Standing, 2014: 30).

All three segments experience a deep sense of deprivation, a painful gap between the lived realities of their lives and their life expectations, but the focus of this gap is different in each case: "the first part of the precariat experiences deprivation relative to a real or imagined past, the second relative to an absent present, an absent 'home', and the third relates to a feeling of having no future" (Standing, 2014: 30-31). These different subjective experiences of deprivation linked to precarity generate serious divisions that undermine the capacity of the precariat to act collectively as class. "The precariat is divided to such an extent", Standing writes, "that one could describe it as a class at war with itself" (Standing, 2014: 29). And yet, in spite of this, he believes that it has the potential to become a "dangerous class" much more capable than the working class of challenging "the mainstream political agendas of the twentieth century, the neo-liberalism of the mainstream 'right' and the labourism of social democracy" (Standing, 2014: 31).

\section{The Precariat's Place in Class Analysis}

There is little doubt that precariousness along a number of dimensions has increased as a condition of life in developed capitalist countries. The question remains how this phenomenon should be understood conceptually. Guy Standing's proposal is that the precariat is a class in the same sense that the working class is a class. He refers to the precariat as a class-in-the-making in deference to the fact that it does not yet act as a unified collective actor - that is, it is not yet a class-for-itself in traditional Marxist terms - but nevertheless, in terms of its structural location within the class structure of capitalism it is a distinct class location, differentiated from the working class and the other classes in

\footnotetext{
${ }^{3}$ In addition to the distinctive properties of the precariat with respect to the three relations which are part of his definition of class, Standing also argues that the precariat has a number of other distinctive features which demarcate it from the working class: the collapse of occupational identity; lack of control over time; detachment from labour; low social mobility; over-qualification; uncertainty; poverty and poverty traps. The logical status of these additional attributes is unclear in the analysis, since they do not constitute part of his explicit definition of the concept of class, and he acknowledges that some of them also apply to segments of the working class. Some of these might be thought of as further elaborations of aspects of the relations of production and relations of distribution, and some of them might be thought of as effects of the primary conditions defining the precariat.
} 
his inventory.

Standing's basic strategy for defending this claim is to argue that there are distinctive conditions that differentiate the lives of the precariat from those of the traditional working class. If taken one by one, he acknowledges there is an overlap between the precariat and parts of the working class, but if taken as a whole these characteristics generate a real boundary of demarcation: "In sum, the precariat is defined by ten features. ${ }^{4}$ Not all are unique to it. But taken together, the elements define a social group, and for that reason we may call the precariat a class-in-the-making" (Standing, 2014: 28).

Standing is quite dismissive of scholars who disagree that the precariat is a class. In particular, he is critical of Marxists, whose "desire to compress the precariat into old notions of 'the working class' or 'the proletariat' distract us from developing an appropriate vocabulary and set of images to guide twenty-first century analysis" (Standing, 2014: 31). The question before us, then, is whether or not sharing this set of socio-economic characteristics elaborated by Standing is sufficient to describe a social category as a class. What, precisely, are the criteria by which we can answer this question?

The most basic criterion which is used in both the Marxist and Weberian traditions of class analysis to answer this question is material interests. There is a poster from around 1979 which shows a working-class woman leaning on a fence; the caption reads: "Class consciousness is knowing which

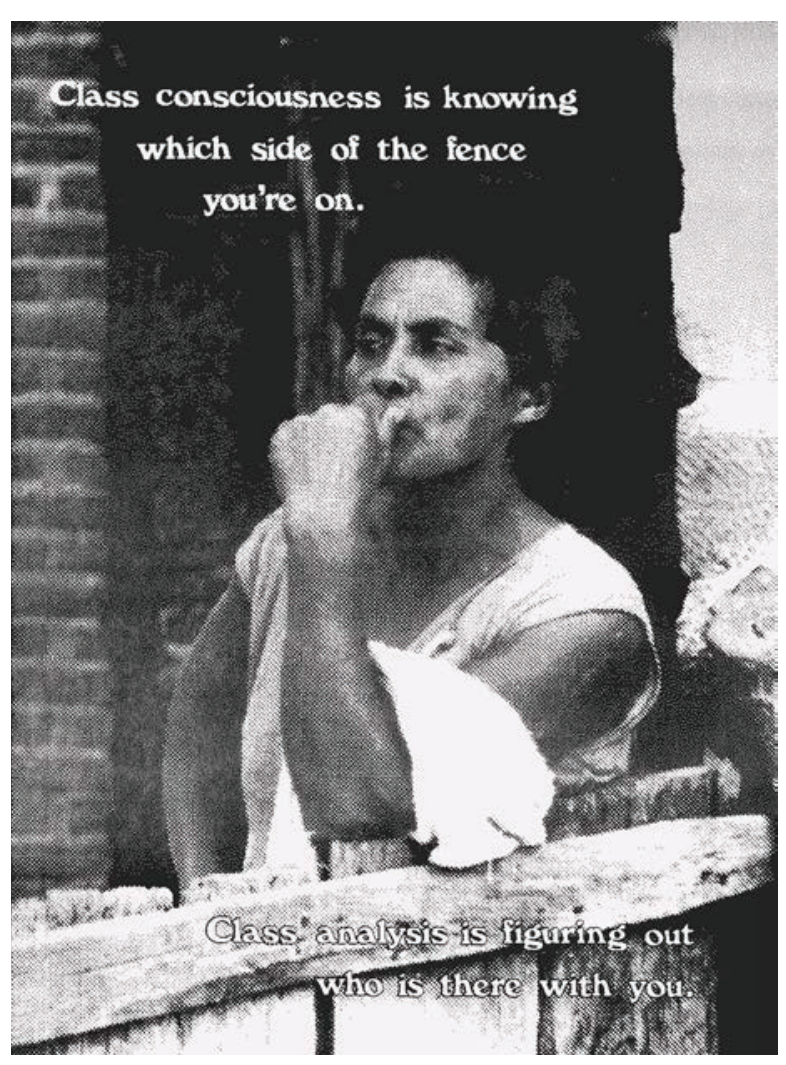
side of the fence you are on. Class analysis is figuring out who is there with you." 5 This is a claim about material interests: two people within a given class have greater overlap in their material interests than do two people in different classes. So, to claim that the working class and the precariat are distinct classes is to claim that they have distinct material interests.

This claim, of course, merely displaces the original question, for now we need a clear criterion for what constitutes "material interests". This is a perennial problem in social theory that raises a host of tricky theoretical issues.

Perhaps the biggest disagreement in discussions of interests is the issue of objective versus subjective interests. Some people argue that the idea of interests is only legitimate when it refers to the subjective states of actors concerning their own understanding of their interests. Others insist that it also makes sense to talk about objective interests. In the first view, the idea of interests is closely connected to preferences. In the second view it is intelligible to say to someone who is about to do something: "You are mistaken, that is not in your interests", which means that interests should not be collapsed into preferences. The concern expressed in this disagreement is that claims about the

\footnotetext{
${ }_{4}^{4}$ These ten features are the three dimensions of class relations plus seven other characteristics (Standing, 2014: 20).

${ }^{5}$ Poster published by Press Gang Publishers, Vancouver, Canada, undated.
} 
"objective interests" of the working class can easily slide into an elite telling the masses what is "good for them". Claims about objective interests have historically been used as a weapon to defend policies imposed by authoritarian parties and states, so there is good reason to be wary of invocations of objective interests. Being wary, however, need not mean dispensing with the idea of objective interests altogether; it just means treating claims about objective interests as propositions rather than authoritative edicts.

In any case, class analysis in both the Marxist and Weberian traditions makes claims about a particular domain of objective interests, which can be identified as "material interests". What this means is the following: for any given person it is possible to identify actions and social changes which would improve or harm their material conditions of life. Sometimes the term "material" is used very narrowly to simply mean income; sometimes it is used expansively to include many aspects of a person's economic situation, including working conditions, opportunities, leisure, economic stability, control over time use, and much more. In both cases the claim is that it is possible to objectively assess the range of strategies and alternatives which will affect these aspects of a person's economic situation. ${ }^{6}$

If we accept the idea that objectively definable material interests are a legitimate criterion for differentiating class locations, the next question becomes how to actually specify these interests with respect to the class structure of contemporary capitalism. This will help us to answer the question of whether the precariat and the working class are distinct classes. For this task it will be useful to elaborate a way of thinking about the strategic contexts of political conflicts introduced by Robert Alford and Roger Friedland (1985: 6-11).

\section{A strategy for specifying different forms of opposing class interests}

Alford and Friedland develop a typology of political struggles in capitalist societies directed at three different forms of power: systemic power, institutional power and situational power. ${ }^{7}$ They use the metaphor of a game to illuminate the distinction across these three kinds of conflicts. Struggles involving systemic power can be thought of as struggles over what game should be played; struggles over institutional power are over the rules of a given game, and struggles involving situational power concern moves within a fixed set of rules. ${ }^{8}$

\footnotetext{
${ }^{6}$ Once a complex array of dimensions is included in "material interests" it will generally be the case that people face tradeoffs in improving one or another of these dimensions. Strategies and social changes that improve economic security may be at odds with those that improve income, for example. To claim that people have objective material interests is not to also claim that they have an objective interest in favouring one or another of the dimensions of those interests where there are trade-offs. The objectivity of material interests in these more complex situations is the objectivity of the trade-offs faced by people. To say that two people have the same objective material interests, then, is to say that they face the same basic trade-offs. To talk about objective material interests is also not to claim that people have some overarching objective interest in actually pursuing their material interests as opposed to some other kind of interest. Frederick Engels, after all, was the son of a capitalist and devoted his time and energy to supporting Marx and the workers' movement. The idea that class interests are "objective" in this case means that when Engels supported revolutionary socialism he was acting against his objective material interests.

7 Alford and Friedland use the term "structural power" instead of "institutional power" for the second of these forms of power, but since they are concerned with the kind of power that operates especially in state institutions, institutional power seems a clearer label.

8 The analogy with sports can help to clarify this framework. Different games give athletes with different physical characteristics different advantages and disadvantages, and thus they have interests in playing one kind of game over another. A world in which only basketball was allowed to be played, for example, would be sharply against the interests of
} 
Politics, then, can be understood as directed at different levels of the game that we call a social system. Revolutionary versus counter-revolutionary politics constitute struggles over what game should be played. In some times and places this was seen by political forces as capitalism versus socialism. Reformist versus reactionary politics within capitalist societies constitute struggles over the rules of the game of capitalism: What kinds of regulations of markets and sectors are permissible? How organised and coordinated should be the principal collective actors in capitalism? What kind of insurance against risks should be provided by the state? The game of capitalism can be played under a wide variety of rules which matter a lot insofar as they give advantages and disadvantages to different kinds of players who play the game; but these all constitute varieties of capitalism. Finally, interest group politics constitute struggles between social forces engaged in moves within a fixed set of rules over immediate interests. Classic examples would be conflicts over spending priorities, tax rates and specific provisions in a tax code.

Real societies, of course, are much more complex than represented in this model. The social system that constitutes a society is not a single, integrated totality in which everything fits together under a unified set of rules. A society is not a system in the same way that an organism is a system. It is more like the loosely coupled system of an ecosystem in which a variety of processes interact in relatively contingent ways. Multiple "games" are being played simultaneously, with often inconsistent rules. Furthermore, it is not always so clear what the distinction is between a change in the "rules of the game" and a change from one game to another. It is always possible that the cumulative effect of small changes in rules can alter the nature of the game to such an extent that eventually a new game is being played. The idea of "evolutionary socialism" can be interpreted as a transformation of the inner nature of the game of capitalism by gradual changes in its rules. Nevertheless, for many purposes it is possible to talk about a dominant game with its internal rules and moves, and this can help to clarify the conceptual status of different currents of class analysis.

\section{Objective class interests at different levels of the game of capitalism}

At the level of the game itself, the Marxist question is this: How would the material interests of people differently located within capitalism be affected by a change of the game from capitalism to socialism? Unless one retains some coherent idea of there being an alternative to capitalism, then a Marxist class analysis loses its central anchor. ${ }^{10}$ These issues pose a serious challenge for contemporary Marxist

short athletes. Once playing a particular game, occasionally the rules themselves are called into question, and changes in the rules can also favour athletes with different attributes. The change in the rules of basketball that allowed players to touch the rim of the basket was in the interests of taller players. And finally, given a set of fixed rules, then the players of the game adopt specific training regimes and strategies in their moves within the game. Dynamically, players invent all sorts of new strategies and ways of training designed to exploit specific opportunities within the existing rules of the game. In time these altered moves in the game begin to change the feel of the game in various ways. Sometimes these changes are seen as eroding the spirit or integrity of the game by spectators, players or "the powers that be" that govern the rules of the game. This can trigger changes in the rules.

9 There are actually two connected questions here: the interests of people connected to different class positions within capitalism in being in a socialist society, and the interests in the transition from a capitalist to a socialist society. Depending on one's view of the likely transition costs of social transformation, one can have unequivocal interests in socialism in the first sense and still not have an interest in trying to achieve socialism. And, of course, such interests in both cases depend on precisely what one means by "socialism".

10 The idea that there is an alternative game to capitalism is deeply controversial. Many people reject the whole idea of socialism of any variety as a viable alternative to capitalism, or they argue that while socialism is possible, almost everyone would be worse off in socialism, and so there is no class differentiation within capitalism at the level of the game. This claim 
work on class. Given the obvious complexity of contemporary class structures, how can we clearly specify the interests of people located within the existing economic structure with respect to something as abstract as "socialism"? It is one thing to define these interests with a simple, binary view of the class relations of capitalism as consisting only of capitalists and workers; it is quite another to locate the interests connected to locations in the complex class structures of capitalism analysed at more concrete levels of analysis.

Trying to solve this problem has been the central preoccupation of my work on class. Without going into any detail here, I have proposed the concept of "contradictory locations within class relations" as a way of connecting the complexity of class structures within capitalism to the alternative of socialism. The basic idea is to identify a series of locations within the class relations of capitalism which were in some sense simultaneously in more than one class. More specifically, with respect to relations of domination and exploitation, some locations can be simultaneously dominated and dominating or exploiting and exploited (Wright, 1985, 1997). In the present context, what this implies is that, with respect to material interests defined in terms of the games of capitalism versus socialism, such locations have contradictory interests.

At the level of the rules of the game, the problem of class interests concerns which set of rules governing capitalism are optimal for different locations within capitalism, given that the people in those positions will continue playing the game of capitalism. Is it better for manual industrial workers to be playing the Game of American Capitalism or the Game of Danish or German Capitalism? What about highly educated workers like doctors or engineers? Do different rules of the capitalist game confer particular advantages and disadvantages on people in different locations in the system? These questions can be asked for the large-scale variations in the rules of capitalism - for example, neoliberal capitalism with a thin safety net and weak provision of public goods versus capitalism with an expansive welfare state and broad provision of public goods and public services - or for second-order variations in the rules. The point is that we can define material interests, and thus the nature of the locations of people in a class structure, with respect to such variations in the rules of capitalism and not simply in terms of the game of capitalism itself.

Finally, at the level of the moves in the game, the problem of class interests concerns the optimal strategies people face in securing and improving their material interests given that the rules themselves cannot be changed. People occupy specific positions in the socio-economic system. The problem each person faces is this: In terms of my material interests, what should I do given that I am in my present position? Should I try to move into a different kind of position (become a different kind of player)? Should I get more training to improve my bargaining position in my current location? Should I move to a different place? Should I join with other people like me in a collective action for mutual improvement, and if so, who are the other people "like me" for this task? This is quite different from asking the question about what sorts of changes in the rules would make my life better, let alone would I be better off in a wholly different game.

\section{Class interests of the precariat and the working class}

Using this metaphor of capitalism as a game, we can now turn to the question of whether the precariat

means, in effect, that all class locations within capitalism have shared material interests against socialism. Others, who do believe that a positive alternative to capitalism is possible, disagree sharply on precisely what "socialism" means, and depending on how socialism is conceived, the terrain of interests within capitalism with respect to the alternative will vary. 
is a distinct class from the working class. How different are the material interests of people in the precariat, as defined by Guy Standing, and in the working class with respect to the game itself, rules of the game and moves within the existing game?

At the level of the game itself, if one believes that a democratic socialist alternative to capitalism is possible, even if not achievable in current historical circumstances, then the precariat and the working class clearly occupy the same location within the class structure. The material conditions of life for people in both locations within capitalism would be enhanced in an alternative economy built around various forms of social ownership, democratic empowerment over broad investment priorities, an expansive sector of decommodified public goods, a cooperative form of market relations, and the other components of democratic socialism. ${ }^{11}$ However, since the collective struggle for such an alternative is not presently on the political horizon, class divisions at the level of rules of the game and moves in the game may be more immediately relevant to the question "is the precariat a class?"

In terms of the rules of the game, it is certainly clear that under the existing rules of capitalism - broadly speaking, the rules of neo-liberal capitalism - the material conditions of life of most people in all three segments of the precariat are worse than those of most people in the working class. Precariousness itself, after all, is a significant harm. But the question we need to ask is not simply whether the precariat is harmed by neo-liberal rules of capitalism, but rather whether there are significant differences in changes in the existing rules of capitalism that would be desirable for the precariat and for the working class. Are they on the same side of the fence or opposite sides when "the fence" is defined by struggles over the rules of capitalism?

Let's first look at changes in rules that would benefit the precariat. In The Precariat Charter, Standing proposes a general inventory of demands for improving the conditions of the precariat. This charter contains 29 Articles (Standing, 2014: 151ff):

Article 1: Redefine work as productive and reproductive activity.

Article 2: Reform labour statistics.

Article 3: Make recruitment practices brief encounters.

Article 4: Regulate flexible labour.

Article 5: Promote associational freedom.

Articles 6-10: Reconstruct occupational communities.

Articles 11-15: Stop class-based migration policy.

Article 16: Ensure due process for all.

Article 17: Remove poverty traps and precarity traps.

Article 18: Make a bonfire of benefit assessment tests.

Article 19: Stop demonising the disabled.

Article 20: Stop workfare now!

Article 21: Regulate payday loans and student loans.

Article 22: Institute a right to financial knowledge and advice.

Article 23: Decommodify education.

Article 24: Make a bonfire of subsidies.

Article 25: Move towards a basic income.

${ }^{11}$ For an exploration of the contours of this conception of democratic socialism as an alternative to capitalism, see Wright (2010: chapters 5-7), and Hahnel and Wright (2016). 
Article 26: Share capital via sovereign wealth funds.

Article 27: Revive the commons.

Article 28: Revive deliberative democracy.

Article 29: Re-marginalise charities.

These are all solid, progressive proposals and, if instituted, they would certainly make a tremendous difference in the lives of people in the precariat. Some of these are quite narrowly directed at the distinctive conditions faced by the precariat, such as Article 4, Regulate flexible labour. Some apply to very specific categories of people, such as Article 19, Stop demonising the disabled. Some of these proposals refer to very narrow rules of the game of contemporary capitalism, such as Article 21, Regulate payday loans and student loans. And some refer to transformations of rules which, if implemented in a serious way, would prefigure an emancipatory alternative beyond capitalism, such as Article 25, Move towards a basic income; Article 26, Share capital via sovereign wealth funds; Article 27, Revive the commons; and Article 28, Revive deliberative democracy. While some of the proposals certainly seem less pressing then others reforming labour statistics is not as pressing an issue as eliminating poverty traps and precarity traps - all of them are in the material interests of people in the precariat.

The question at hand, however, is not simply whether these proposals serve the interests of the precariat, but whether or not they provide grounds for claiming that the precariat is a class distinct from the working class. Is there a divide in material interests between the precariat and the working class with respect to this charter of proposed changes in the rules of the game of capitalism? The answer, I think, is no: None of these proposed changes in the rules of the game go against the material interests of the working class, and nearly all of them would significantly advance the interests of workers. While these proposals may matter more for the lives of people in the precariat than for those still in the stable working class, they are in the interests of both kinds of locations within the class structure of capitalism. This is, however, not true for everyone in capitalism. For the plutocratic elite as defined by Standing, the enactment of the articles in this charter would certainly impinge on their power, wealth and autonomy. The same would be true for much of the salariat, especially for the wellpaid segments of the corporate hierarchy. For proficians some of the articles in the charter would be innocuous, but many would interfere with their advantages. If we use the 29 Articles of the Precariat Charter as a diagnostic test of class locations with respect to the rules of the game, the precariat and the working class are parts of the same class.

The diagnosis becomes somewhat more complicated when we ask if there are significant other changes in the rules of the game that would advance the interests of most people in the working class but which would be harmful for the precariat. For example, would changes in employment law that would increase job protections for workers by making it harder for workers to be laid off have the side-effect of harming the precariat? What about legal changes in the United States that made unionisation easier by restricting the anti-union strategies of employers? There are some real ambiguities here, for these kinds of changes in the rules could have the side-effect of deepening the dualism in the labour market and making it harder for people in precarious positions to move into more stable jobs. But it is also possible that strengthening labour law, union rights and job protections would be accompanied by expanded job training, increased income support and other provisions of value to at least some parts of the precariat.

These ambiguities are a basis for considering the precariat to be a distinct segment of the working class at the level of the rules of game. Different segments of a class share the same general interests 
over the optimal rules of the game within capitalism, but differ in the relative priority of potential changes in the existing rules and may have opposing interests over specific rules in certain historical contexts. The issues here are quite complicated, for while it is true that, taken in isolation, things like increases in job protection for employed workers might harm the precariat, the political conditions that would actually make possible a serious revitalisation of job protections and union capacities would also lead to policies beneficial for many in the precariat segment of the working class. The extent of actual conflicts of interests over changes in the rules of the game between the precariat and the rest of the working class, therefore, is contingent on the character of the political processes which organise such struggle.

Another possible way to understand these tensions between the precariat and other segments of the working class is to interpret them as reflecting a specific kind of contradictory location within class relations in twenty-first century capitalism. The idea here would be that those workers who still actually have enforceable rights to their jobs - the most secure, if dwindling, part of the working class - have a kind of limited property right which normally is associated with owning the means of production: the right to fire an employee. They can quit, but they cannot be fired. Fully proletarianised workers lack such rights, much like the mid nineteenth century factory workers of the industrial revolution who lacked all rights and job protections. Those workers with such quasi-property rights in their jobs are thus in a distinctive kind of contradictory location within class relations. ${ }^{12}$ In this way of framing the problem, much of the precariat is firmly in the working class along with other workers who lack such strong job rights, while the most securely protected workers occupy a privileged contradictory class location.

What about class locations defined with respect to the moves in the game? Perhaps the precariat and the working class are distinct classes when class is specified in this way. Two problems arise with this proposal. First, the working class itself ceases to be "a" class if we restrict the specification of class to moves in the game. The material interests of workers located in different sectors and occupations can easily diverge sufficiently to create lines of demarcation so long as interests are defined exclusively with respect to moves in the game rather than rules of the game. Second, the precariat itself is internally divided into distinct categories at this level of analysis, as Standing himself acknowledges. Again, while people in all subcategories of the precariat may share common interests embodied in the Precariat Charter, they do not share common interests defined by available strategies of action under the existing rules of neo-liberal capitalism. The optimal moves-in-the-game for undocumented migrant labour and over-qualified unemployed youth are very different within the existing rules of the game.

What are we are left with then? The precariat is either a part of the working class if class is analysed in terms of the basic rules of the game of twentieth-century developed capitalism, or it is itself an aggregation of several distinct class locations if class is defined narrowly in terms of homogeneous interests defined by moves in the game. The precariat, as a rapidly growing segment of the working class and the bearer of the sharpest grievances against capitalism, may have a particularly important role to play in struggles over the rules of capitalism and over capitalism itself, but it is not

\footnotetext{
12 A contradictory location within class relations is simultaneously in more than one primary class. Workers with these strong rights to their jobs in a sense partially "own" their jobs, and thus are like the petty bourgeoisie. The idea that enforceable job security is a form of property rights was suggested by Philip van Parijs (1989).
} 
a class in its own right.

One response to this is, "So what? Who cares?" The salience of precariousness as part of the condition of life for millions of people in the world today does not depend on whether people in such positions are viewed as being in a distinct class. What matters is the reality of the conditions they face and what can be done about it. It is also certainly the case that in some rhetorical contexts calling the precariat a class could help elevate the status of the issues connected to precariousness and serve as a way of legitimating and consolidating a programme of action. This, I think, is what Standing intends by his Precariat Charter. But, if class analysis is also meant to help us develop a coherent, consistent way of theoretically understanding social cleavages and the possibilities of transformation, then it becomes important that the concepts we use have precise meanings that illuminate the nature of shared and conflicting interests and potential collective capacities. And for these purposes, treating the precariat as a class - even as a class-in-the-making - obscures more than it clarifies.

\section{REFERENCES}

Alford, R. and R. Friedland (1985) The Powers of Theory: Capitalism, the State, and Democracy. Cambridge: Cambridge University Press.

Hahnel, R. and E.O. Wright (2016) Alternatives to Capitalism: Proposals for a Democratic Economy. London and New York: Verso. Also vailable online as an e-book at www.newleftproject.org/index.php/site/article_comments/alternatives_to_capitalism_proposals_for_ a_democratic_economy.

Standing, G. (2011) The Precariat: The New Dangerous Class. London and New York: Bloomsbury.

Standing, G. (2014) The Precariat Charter: From Denizens to Citizens. London and New York: Bloomsbury. Van Parijs, P. (1989) A Revolution in Class Theory. In The Debate on Classes, edited by E.O. Wright. London and New York: Verso.

Wright, E.O. (1985) Classes. London and New York: Verso.

Wright, E.O. (1997) Class Counts. Cambridge: Cambridge University Press.

Wright, E.O. (2010) Envisioning Real Utopias. London and New York: Verso.

Wright, E.O. (2015) Understanding Class. London and New York: Verso

\section{BIOGRAPHICAL NOTE}

ERIK OLIN WRIGHT is Vilas Distinguished Research Professor at the University of Wisconsin, Madison. His academic work has been centrally concerned with reconstructing the Marxist tradition in ways that attempt to make it more relevant to contemporary concerns and more cogent as a scientific framework of analysis. His empirical work has focused especially on class analysis. Since 1992 he has directed The Real Utopias Project, which explores a wide range of proposals for new institutional designs that embody emancipatory ideals and yet are attentive to issues of pragmatic feasibility. He was president of the American Sociological Association in 2011-2012. His principal books include: Class, Crisis and the State (1978); Classes (1985); Reconstructing Marxism (1992); Class Counts (1997); Deepening Democracy (with Archon Fung, 2003); Envisioning Real Utopias (2010); American Society: How It Really Works (with Joel Rogers, 2011 and 2015); Understanding Class (2015); and Alternatives to Capitalism (with Robin Hahnel, 2016). [Email: eowright@wisc.edu] 